$\mathrm{JMB}$

1,1

Received 26 May 2021 Revised 4 July 2021 Accepted 12 July 2021

\section{Corporate performance volatility: a micro-level perspective}

\author{
Rexford Abaidoo \\ Business Management and Accounting, University of Maryland Eastern Shore, \\ Princess Anne, Maryland, USA, and \\ Elvis Kwame Agyapong \\ Ghana Institute of Management and Public Administration, Accra, Ghana
}

\begin{abstract}
Purpose - This study examines how specific micro-level macroeconomic indicators influence corporate performance volatility among US corporate bodies in the short run.

Design/methodology/approach - The study employs error correction autoregressive distributed lagged (ARDL) model (ECM) to examine how micro-level variables influence volatility associated with corporate performance in the short run.

Findings - This paper finds that disaggregated or micro-level variables examined, tend to exhibit features that are not readily apparent from the aggregate variable from which such variables are derived. For instance, reported empirical estimate suggests that, growth in expenditures on services and nondurable goods tend to lower volatility associated with corporate performance, whereas government expenditures and expenditures on durable goods rather worsens volatility associated with corporate performance, all things being equal. Additionally, presented empirical estimates further provide evidence suggesting that macroeconomic uncertainty and inflation uncertainty significantly moderate or influence the extent to which disaggregated variables impact corporate performance volatility.

Originality/value - Compared to related studies in the reviewed literature, this study rather examines volatility associated with corporate performance instead of the corporate performance indicator itself. Additionally, this paper also examines how disaggregated variable instead of aggregate variables impact such volatility. Finally, the moderating role of key macroeconomic conditions in such a relationship is also examined.
\end{abstract}

Keywords Corporate performance volatility, Disaggregated macroeconomic variables, Inflationary uncertainty, Macroeconomic uncertainty and ARDL model

Paper type Research paper

\section{Introduction}

Firm and corporate performance indicators in a dynamic macroeconomic environment are subject to significant fluctuations. Such fluctuations, which are often occasioned by constantly evolving macroeconomic conditions and indicators, constitute one of the prime conditions of interest consistently monitored by shareholders and potential investors. Volatility associated with firm or corporate performance in an evolving macroeconomic environment is not only crucial for shareholders and potential investors but also critical to individual firms and institutions in the business environment for strategic purposes. Firms in a highly competitive environment constantly review dynamic trends and performance among perceived competition to gauge strength and potential weaknesses for the purposes of gaining a competitive edge. In the theory of the firm, the extent of variability among

\section{JEL Classification — E32, E62, G32, L25}

(C) Rexford Abaidoo and Elvis Kwame Agyapong. Published in Journal of Money and Business. Published by Emerald Publishing Limited. This article is published under the Creative Commons Attribution (CC BY 4.0) license. Anyone may reproduce, distribute, translate and create derivative works of this article (for both commercial and non-commercial purposes), subject to full attribution to the original publication and authors. The full terms of this license may be seen at http://creativecommons. org/licences/by/4.0/legalcode
Journal of Money and Business Vol. 1 No. 1, 2021 pp. $42-63$

Emerald Publishing Limited e-ISSN: 2634-260X

p-ISSN: 2634-2596

DOI 10.1108/JMB-05-2021-0013 
performance indicators of interest, and the persistence of the condition over time, often impacts shareholder and investor confidence, a condition which may ultimately define the magnitude of investments, firms or corporate entities attract, all things being equal. (refer to Nunes et al., 2012; Utama and Sulistika, 2015; Perić and Đurkin, 2015; Grazzi et al., 2016). The reviewed literature suggests that empirical inquiries focusing on corporate or firm performance over the years have employed varying indicators as proxies in measuring and defining such an indicator. The related literature, for instance, highlights significant diversity among indicators often used as proxies for firm or corporate performance. Indicators such as the return on equity (ROE), return on assets (ROA), stock returns, Tobin's $Q$, market value of equity to book value of equity, price per share to earning per share ratio, market value of equity and book value of liabilities to book value of equity ratio, and total shareholder return among others have all been used extensively. (see Demsetz and Villalonga, 2001; Adams et al., 2005; Zeitun and Tian, 2007; Becchetti et al., 2008; Aras et al., 2010; Ntim and Osei, 2011; Baños-Caballero et al., 2014). Although occasional debate still exists about the superiority of some of the variables or indicators often used as proxies [1] for firm or corporate performance, the importance of performance indicators to investors, strategic decision-making and assessment of the health of the global economy as a whole cannot be overstated. One of the major forces, which have and continue to influence a significant portion of the variability in firm/corporate performance has been the capricious nature of the macroeconomic environment within which firms and corporate bodies operate.

The fundamental relationship between corporate or firm performance, and the macroeconomic environment within which such entities operate, constitutes one of the core features of interest in business strategy. Growing interest in this constantly evolving relationship stemming from the need to adapt to the transient nature of macroeconomic conditions has witnessed significant empirical inquiry over the years in the prominent finance and economics literature. Ongoing interest in studies focusing on the relationship in question can be attributed mainly to the need to minimize firm or corporate performance vulnerability to macroeconomic shocks or threats, and the desire among business strategists to reduce the inimical impact that adverse macroeconomic conditions may have on corporate or firm performance or return. Studies such as Zeitun and Tian (2007), Demsetz and Villalonga (2001), Benerje and De (2014), Igbinosa (2015), etc. have, for instance, provided critical insight on some of the core variables and conditions explaining observed variability in corporate/firm performance. Further review of related empirical studies examining factors or conditions responsible for variability in corporate/firm performance, suggests that most of such studies are dominated by how aggregate macroeconomic variables or conditions, and firm-specific or industry-specific factors influence corporate/firm performance. (see Adams et al., 2005; Zeitun et al., 2007; Asimakopoulos et al., 2009; Apadore and Zainol, 2014; Palaniappan, 2017; Mahadalle and Kaplan, 2017; Doruk, 2019; Rahman et al., 2020). For instance, an in-depth review of the extant literature on corporate or firm performance suggests that most studies examining the relationship in question focus primarily on the role of aggregate macroeconomic conditions or variables such as the gross domestic product (GDP) growth, inflation, exchange rate, etc., and firm-specific factors such as size, form of leadership, etc. in corporate or firm performance.

Unlike most reviewed studies (most of which have been cited above), this study adopts a different approach in its inquiry focusing on the mechanics of corporate performance. In this proposed approach, instead of focusing on corporate or firm performance as the core variable of interest (dependent variable) as done in most existing studies (see Zeitun et al., 2007; Asimakopoulos et al., 2009; Aras et al., 2010; Baños-Caballero et al., 2014; Palaniappan, 2017; Rahman et al., 2020), we rather focus on the volatility associated with corporate performance and not the performance indicator itself. This approach stems from the presumption that although performance indicators are of interest to both shareholders and potential investors,

\section{Corporate performance volatility}


these economic agents may be much more interested in the extent of variability associated with such a performance indicator since such a condition ultimately influences returns. Additionally, contrary to the growing focus on how traditional aggregate macroeconomic variables (GDP growth, inflation etc.) influence corporate performance, this study rather examines how disaggregated macroeconomic variables or subcomponents of key macroeconomic indicators influence corporate performance volatility in the short run. Corporate performance volatility, the dependent variable examined in this study, defines empirically estimated/simulated fluctuations or volatilities associated with corporate performance over a period. On the other hand, the corporate performance indicator (variable), the base variable from which the corporate performance volatility variable is derived, defines corporate profit growth after tax and inventory valuation adjustments over a period of time (variable constructed by the US Federal Reserve). In order words, apart from this study's unique approach in focusing on volatility associated with corporate performance, the study also examines the impact of subcomponents of the key macroeconomic variable (instead of aggregate level variables) on the volatility inherent in corporate performance over the study period.

Empirical inquiry into the extent to which disaggregated macroeconomic variables and other external macroeconomic conditions influence corporate performance volatility revolves around the contingency theory of organizations. The contingency theory of organizations surmises that organizational effectiveness (performance), all things being equal, results from fitting characteristics of the organization (structure) to different contingencies such as environmental conditions, organizational size and strategy. In order words, according to the contingency theory of organization, firm or organizational effectiveness/performance is a function of both external/environmental conditions, as well as organization-specific factors such as size, strategy, form of leadership, etc. This study, as per the defined objective, focuses on the environmental or external slant of the contingency theory of organizations by examining how subcomponents' macroeconomic variables and other external macroeconomic conditions influence corporate performance volatility among corporate entities in the United State.

This study's projected contributions to the existing literature on firm or corporate performance, therefore, revolves around the focus on corporate performance volatility instead of corporate performance, and the role of subcomponent macroeconomic variables instead of mostly aggregate variables often employed in most studies. The disaggregated determinants approach adopted in this study has been informed primarily by two main assumptions. First, we surmise that macro-level analysis based on aggregate indicators such as the GDP growth, for instance, may shroud or fail to capture the full spectrum of micro-level channels through which the variable (GDP growth) ultimately influence corporate or firm performance and, for that matter, the volatility inherent in such an indicator. Secondly, we also posit that the subcomponents analysis approach adopted in this study has the potential to highlight hitherto undetected micro-level interactions between key subcomponent variables and corporate performance volatility. For instance, it is conceivable that only one or few subcomponents of the key aggregate variable (e.g. GDP growth) may be responsible for the observed relationship often attributed to its aggregate variable. Consequently, we are of the view that the subcomponents approach adopted in this study has the potential to uncover critical micro-level channels that might not be apparent at the aggregate level.

Potential associations between subcomponent variables and corporate performance volatility, which may be unearthed in subsequent analysis, could be essential for strategic decision-making, and serve as a framework for continual assessments on how specific microlevel indicators influence performance and returns. For instance, hitherto unknown interactions that may be uncovered could help inform development of specific strategic 
policies geared toward reducing vulnerability associated with corporate performance to such specific sub-macroeconomic indicators. For instance, a verified significant association between expenditures on services and corporate performance volatility could aid efforts in developing strategies designed to either curtail or enhance effects of such a sub-macroeconomic indicator on performance volatility. Additionally, understanding of how key micro-level components of a major variable impact corporate performance volatility could help shareholders appreciate occasional trend volatility associated with key variables that ultimately influence returns. This is crucial in that a decline in the GDP growth, for instance, might not necessarily influence how all its subcomponents ultimately influence firm or corporate performance. For instance, a decline in the GDP growth, occasioned by a decline in government expenditure, might not necessarily impact corporate or firm performance if such performance is rather found to depend heavily on the consumption growth, all things being equal.

The rest of this study proceeds as follows: Section two critically examines historical trends in corporate performance and corporate performance volatility over the study period. Section three reviews the related literature focusing on corporate performance in general and corporate performance volatility specifically if any. Section four empirically models corporate performance volatility and macroeconomic uncertainty; this is followed by a section on methodology, data sources and development of the main empirical model for the study. The last two sections present empirical estimates and analysis of key findings of the relationships between subcomponents of macroeconomic indicators and corporate performance volatility. The section also examines effects of macroeconomic uncertainty and inflation uncertainty on corporate performance volatility. The study concludes with a summary of key findings and the potential strategic or policy implications of major findings.

\section{Corporate performance and corporate performance volatility - a graphical analysis}

The corporate performance growth variable, from which this study derives corporate performance volatility, is based on the US after tax corporate profit growth with inventory valuation adjustment. This section examines historical trend conditions associated with corporate performance and corporate performance volatility variables over the period under review. Figures 1 and 2 presented below are intended to graphically highlight historical trend characteristics of the variables over the period in question in order to verify if trend features exhibited by these two variables over the study period reflects any observed macroeconomic condition. Figure 1 in this regard charts the quarterly corporate performance growth variable (after tax corporate profits growth with inventory valuation adjustments) from 1960 to 2020. As expected, the corporate performance trend over the period under study is characterized by significant variability; however, the most significant feature associated with the variable over the period under review according to Figure 1, is how the trend was influenced by a major macroeconomic phenomenon over the period. Critical analysis of the graphical trend over the study period suggests that significant volatility spread (highest trough and peak in fluctuations) over the period under review coincided with the most recent US recessionary period (2007-2009) brought about by the US mortgage crisis. This extreme trend feature captured at the far right of Figure 1, to some extent, highlights the impact or role that macroeconomic conditions such as recession may play in influencing fluctuations associated with corporate performance. From Figure 1 it is evident that although corporate performance over the study period experienced significant fluctuations, major decline and spike experienced between 2007 and 2009 could be attributed mostly to the incidence of recessionary conditions over the period.

Compared to Figure 1, Figure 2 plots quarterly percentage change in corporate performance volatility instead of corporate performance variable as done in Figure 1.

\section{Corporate performance volatility}


$\mathrm{JMB}$

1,1

46
30
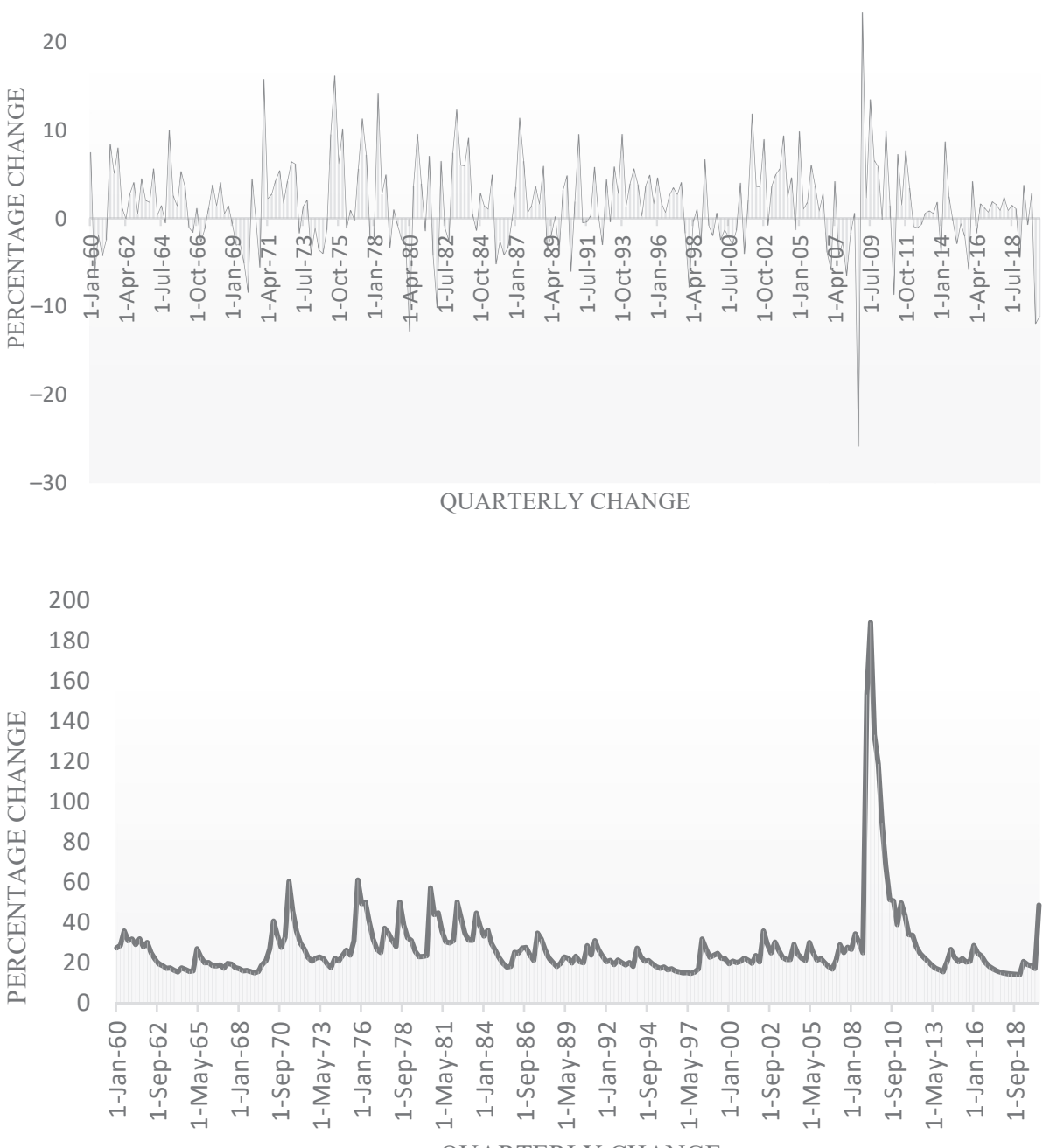

QUARTERLY CHANGE
Figure 1.

Quarterly corporate performance (1960-2020)
Figure 2.

Quarterly corporate performance volatility (1960-2020)
The critical assessment of trend conditions captured in Figure 2 suggests different trend dynamics compared to the absolute corporate performance variable trend captured in Figure 1. Figure 2 suggests that trends in corporate performance volatility over the study period are more extreme compared to what the actual indicator (captured in Figure 1) seems to project in terms of quarterly percentage change. Again, a conspicuous spike in the corporate performance volatility trend captured around 2007 and 2009 in Figure 2 further highlights the potential influence of prevailing recessionary conditions at the time. This concise graphical analysis, to some extent, points to the crucial role or importance of macroeconomic conditions and key macroeconomic indicators in corporate or firm performance. With this background, this study examines the role that micro-level 


\section{Overview of the literature}

The existing literature on corporate or firm performance is characterized by significantly diverse empirical studies, each designed to examine the role of varied factors and conditions in firm/corporate performance. Most of these studies, unlike what is being pursued in this study, focused primarily on the extent to which two broad categories of factors (corporate or firm-specific factors, and external or macroeconomic factors) influence trend dynamics in corporate/firm performance. In this reviewed literature, however, three principal approaches are examined: the first focuses mainly on strands of empirical studies making the case for superior effects of firm-specific or corporate-specific factors in firm or corporate performance. The second strand of empirical studies focuses mainly on the role of external or macroeconomic conditions in corporate performance, and the third and final form of empirical studies takes a hybrid approach, where the role of both firm-specific and external macroeconomic conditions in corporate performance are examined. Studies such as Hansen and Wernerfelt (1989), Pantea et al. (2014), and Asimakopoulos et al. (2009) have submitted evidence alluding to the importance of both firm-specific and macroeconomic factors in corporate/firm performance. On the other side of the spectrum, studies such as Agustinus and Rachmadi (2008), Zeitun et al. (2007) and Coad (2009) rather make the case for stronger impact of macroeconomic factors on firm performance as opposed to the role of firm- or corporatespecific factors. For instance, Triandafil et al. (2010) provided evidence suggesting that macroeconomics-related variables are the prime determinants of corporate profitability. Additionally, Doruk (2019) used firm-level dataset to verify the effect of factors such as trade openness, the financial depth, economic growth and foreign exchange rate for the manufacturing sector of the Turkish economy from 2006 to 2017 using the generalized method of moments (GMM) estimation technique. The results showed that macroeconomic conditions are key determinants of firm performance. Again, using stock returns to proxy for firm performance, Barakat et al. (2016) studied the nexus between macroeconomic indices and performance for the Egyptian and Tunisian economies from 1998 to 2014. Barakat et al. (2016) concluded that for both economies, the exchange rate, money supply and interest rate affect stock returns, whilst inflation was found to exert an influence on stock returns for the Egyptian economy but not for the Tunisian economy. Issah and Antwi (2017) also used ROA to represent firm performance in a study that used data from the UK in verifying the effect of macroeconomic factors on performance. The study concluded that overall, firm performance is a function of macroeconomic variables. For the US economy, Shu et al. (2013) assessed the impact of macroeconomic factors in forecasting earnings of firms from 1962 to 2009. The results of the study revealed a heterogenous impact exerted on earnings by macroeconomic indices; diverse effects across industries and time periods were observed. Geetha et al. (2011) concluded that for the US, Chinese and Malaysian economies, expected and unexpected inflation have a significant relationship with stock returns (performance) in the long run. In the short run, however, they could not confirm a relationship between these variables (expected and unexpected inflation) and stock returns for the US and Malaysian economies, but confirmed the nexus for the Chinese economy. Sir (2012) also approached the subject by examining the effect of macroeconomic variables on stock market returns for the UK and German economies from February 1999 to January 2011. The study found out that there exist short-run and long-run relationships between macroeconomic variables and stock prices.

The case for the importance of firm-specific or industry-specific factors in corporate/firm performance is also well documented in the literature, and studies such as Kemper et al. (2013), Zeitun and Tian (2007), and Pervan and Visic (2012), to name but a few, have argued in favor
components or the subcomponents of key macroeconomic variables and other macroeconomic indicators play in corporate performance volatility.

\section{Corporate volatility \\ volatility} performance

47


of the importance of firm or corporate-specific factors in corporate performance. Conclusions presented in this succinct [2] overview of the literature on firm/corporate performance suggest that a varied combination of factors or conditions ultimately influence any observed significant variability associated with firm/corporate performance at any point in time.

There has also been a significant inquiry into firm performance in the literature in recent years. Islam and Sahajalal (2021), for instance, approached the subject matter by examining the macroeconomic factors that affect the profitability of pharmaceutical firms in Bangladesh from 2000 to 2018. The results showed that GDP, inflation and the real exchange rate exert insignificant positive influence on profitability measured by ROA, whilst the interest rate was found to significantly affect ROA adversely. Rezina et al. (2020) found the GDP growth and real interest rate to have a positive effect on profitability (ROA), whilst inflation was found to exert a negative impact on profitability. Focusing on the banking industry in Pakistan, Rahman et al. (2020) employed the GMM estimation technique in verifying the determinants of profitability from 2003 to 2017 . The study revealed that macroeconomic variables such as the interest rate and industrial production exert negative influence on profitability. Again, using the GMM estimation approach, Doan (2020) studied the determinants of profitability (ROA) of the real estate industry in Vietnam from 2010 to 2018 and found the inflation rate and economic growth as the external factors impacting the rate of growth of firm profitability. Putra et al. (2021) also focused on examining the macroeconomic determinants of profitability of regional development banks in Indonesia from 2012 to 2020 . The study revealed that economic growth, inflation and bank certification have significant positive effect on profitability. Panda et al. (2021) also identified changes in economic growth and banks' advances to small-scale industries as having a significant positive impact on profitability of small and medium enterprises in India for a study that employed the feasible generalized least squares estimation technique from 2010 to 2017. For listed commercial banks on the Bombay Stock Exchange in India, on the other hand, Al-Homaidi et al. (2020) found GDP and inflation to have an adverse significant effect on profitability (ROA). Killins (2020) who also focused on the insurance industry in Canada in a study on the subject matter identified real GDP growth and equity market returns to have a significant impact on profitability.

From the above reviewed literature, it is evident that the existing literature abounds with host of empirical studies focusing on corporate/firm performance. The review further suggests that studies focusing specifically on volatility associated with corporate performance, and conditions or factors accounting for such volatility as being pursued in this study are rare. A thorough survey of the literature on firm or corporate performance did not find any study, which specifically examines the form of micro-level relationships being examined in this study. The empirical analysis closest to what this study seeks to examine found in the literature were studies by Faccio et al. (2011) and Bruno and Shin (2014), respectively. However, even in these studies, researchers rather examined the role of leverage (firm-specific feature) in firm performance volatility instead of the disaggregated macroeconomic variables approach adopted in this study. Apart from this distinction, the performance volatility indicator employed in these studies (Faccio et al., 2011; Bruno and Shin, 2014) are also different from what is employed in this study. The present literature, therefore, lacks studies specifically designed to verify potential effects of micro-level variables on corporate performance volatility as done in this study. This study, therefore, has the potential to fill a critical gap in the firm/corporate performance literature.

\section{Modeling corporate performance volatility and macroeconomic uncertainty variables}

This section empirically derives two explanatory variables, which do not exist as absolute data values in an available database through an econometric procedure. Unlike other 
variables examined in this study, corporate performance volatility and macroeconomic uncertainty variables are derived through an econometric process. The econometric procedure in question involves deriving these two variables from related base indicators or variables. The two variables are derived from the quarterly corporate performance variable and GDP growth variable, respectively. Corporate performance volatility in this instance is derived from the corporate performance variable, and the macroeconomic uncertainty variable is derived from the GDP growth. The two variables are derived from these base indicators using the Generalized Autoregressive Conditional Heteroskedastic Framework $(\mathrm{GARCH})$. The GARCH $(1,1)$ econometric procedure employed in this study was originally proposed by Bollerslev (1986) as a generalization of Engle's (1982) Autoregressive Conditional Heteroskedasticity $(\mathrm{ARCH})$ framework. It is important to point out that the use of GARCH $(1,1)$ in deriving volatility associated with a base variable is not new; the econometric procedure has been used extensively in the finance and economics literature. For instance, studies such as Fang et al. (2008), Fountas and Karanasos (2007), Asteriou and Price (2005), Lee (2010), Chapsa et al. (2011), etc. all used the procedure in estimating uncertainty and volatility variables in their respective empirical studies. The GARCH $(1,1)$ procedure captures uncertainty or volatility as the variance of the stochastic or unpredictable component of a specific variable in treatment, in this case, the base variables from which new variables are derived. Estimating uncertainty or volatility from fluctuations associated with a base variable is based on the assumption that in a macroeconomic environment, fluctuations characterizing key indicators of interest create uncertainty among investors, potential investors and consumers in general, which ultimately influence investments and expenditure choices. The GARCH function estimating volatility/uncertainty associated with corporate performance and economic growth (GDP) is modeled as follows:

$$
Y_{t}=\mu+\alpha Y_{t-1} \varepsilon_{t-1}^{2}+\beta_{1} Y_{t-1}
$$

Where $Y_{t}$ captures volatility inherent in a specific base variable/s in treatment, $\varepsilon_{t-1}^{2}$ the most recent error squared, and $Y_{t-1}$ the prior estimate of the conditional variance produced by the model. $\mu>0, a$ and $\beta>0$ are assumed to ensure a positive $Y_{t}$. The new variables derived via this procedure are examined in a subsequent empirical analysis verifying how disaggregated components or subcomponents of the macroeconomic variable influence corporate performance volatility.

\section{Model specification and data}

This study employs quarterly time series data spanning the period 1960 to 2020 in its estimation of how disaggregated macroeconomic variables influence corporate performance volatility. Time series, data used in the various empirical tests performed in this study are sourced from the US Federal Reserve Economic Data (FRED) St. Louis Fed. Key variables sourced from the database include corporate profit growth (corporate performance) from which the corporate performance volatility (Corp PV) variable is derived and GDP growth from which the macroeconomic uncertainty variable (MacroUnc) is also derived. These two variables are derived using a GARCH process as already alluded to. Other variables sourced from the same US federal agency include components of GDP growth, namely expenditure on services (Exp Ser), expenditure on nondurable goods (Exp NDG), government expenditure (Gov't Exp) and expenditure on furable goods (Exp DG). Other explanatory variables such as investment growth (investments), exports and inflation [3] examined in the study are also sourced from the same data repository. Empirical analysis performed in this study focuses primarily on short-run dynamics of corporate performance volatility using the autoregressive distributed lag framework (ARDL). The focus on the short-run dynamic association between mostly micro-level variables and corporate performance volatility has

\section{Corporate performance volatility}


$\underset{1,1}{\mathrm{JMB}}$

been informed mainly by how most performance indicators react to prevailing macroeconomic conditions. Short-run analysis pursued in this study is based on the assumption that volatility associated with most performance indicators are often transient in nature because such performance mostly moves in tandem with fluctuations in the macroeconomic environment within which such firms or corporations operate. Additionally, adoption of the ARDL methodology further reflects the framework's proven ability to capture short-run dynamic interactions between defined variables of interest.

\section{The autoregressive distributed lagged model}

The dynamic relationship between corporate performance volatility and micro-level macroeconomic variables is examined using the ARDL framework similar to one used in a study by Ahmed and Qayyum (2007). Although the empirical evidence suggests that the ARDL framework from which the study derives the error correction model generates statistically significant estimates irrespective of the order of integration of variables in treatment according to Pesaran et al. (2001) [4], we opt to provide unit root tests as a preestimation inquiry examining the stationary characteristics of the variables examined in this study. Additionally, evidence provided by Alam and Quazi (2003), further suggests that the ARDL test procedure generates robust estimates even in instances where explanatory variables in treatment are endogenous; thus, the error correction procedure based on the ARDL framework is not constrained gravely by endogeneity, a feature which further minimizes the need for the post-estimation endogeneity test. The ARDL function modeling surmised associations examined in this study are formulated in a generic format as follows:

$$
\Gamma_{t}=\partial+\delta_{1} \Gamma_{t-1}+\delta_{2} \gamma_{t-2}+\ldots+\delta_{k} \gamma_{t-k}+\mu_{t}
$$

where $\Gamma_{t}$ defines the vector of volatility associated with corporate performance; $\gamma$ is the vector of disaggregated macroeconomic variables surmised to explain modeled volatility in corporate performance. $\partial$ defines the constant term in the equation, and $\mu_{t}$, the equation error term assumed to be (iid) with $\left(0, \sigma^{2}\right)$. To estimate the extent to which disaggregated and other explanatory macroeconomic variables influence corporate performance volatility in the short run, a difference notation in the form, $\Delta=1-l$ is defined, where $l$ in this instance captures the lag operator. From this notation, an error correction model (Ecm) examining the effects of various explanatory variables on corporate performance volatility from equation (2) is derived as follows:

$$
\Delta \Gamma_{t}=\partial+\sum_{i=1}^{p-1} \eta_{i} \Delta \Gamma_{t-i}+\delta \gamma_{t-k}+(\mathrm{Ecm})_{t-1}+\mu_{t-k}
$$

In equation (3), $\Delta$ represent the difference operator, $\Gamma$, the notation capturing corporate performance volatility, $\delta \gamma$ defines various disaggregated macroeconomic variables in treatment, $(\mathrm{Ecm})_{t-1}$ captures the error correction function and $\mu$ is the error term. From equation (3), error correction function $(\mathrm{Ecm})_{t-1}$ which estimates the speed of adjustment from deviations toward equilibrium can also be derived as follows:

$$
(\mathrm{Ecm})_{t-1}=\Delta \Gamma_{t}-\partial-\sum_{i=1}^{p-1} \eta_{i} \Delta \Gamma_{t-i}-\delta \gamma_{t-k}-\mu_{t-k}
$$

This study employs the ARDL model captured in equation (3), to examine short-run relationships if any, between the noted disaggregated and other macroeconomic variables and corporate performance volatility. Equation (4), as indicated earlier, specifically estimates the speed of adjustment toward equilibrium in the long run from deviations or distortions. 


\subsection{Descriptive statistics}

Table 1 reports summary statistics to highlight core features of the underlying data employed in examining various micro-level analysis pursued in this study. The values for asymmetry or skewness between -2 and +2 are considered acceptable, suggesting that underlying data are normally distributed (see George and Mallery, 2010; Hair et al., 2010; Bryne, 2010).

\subsection{Correlation analysis}

This section preliminarily verifies underlying relationships between explanatory variables employed in the study and corporate performance volatility. Correlation results presented in Table 2 are not intended to suggest or attribute any form of causal association between the dependent variable and various explanatory variables in the study. The goal, however, is to highlight fundamental relationships between core variables in the study. Correlation results presented in the first column of Table 2 suggest that with the exception of the macroeconomic uncertainty variable, all the explanatory variables examined in the study correlate negatively with corporate performance volatility. Correlation results presented in column 1 of Table 2 , in this instance, lay the foundation for subsequent empirical tests and analysis verifying factors influencing corporate performance volatility.

\section{Corporate performance volatility: the role of uncertainty and micro-level variables}

This section empirically tests, and critically analyzes the extent to which various disaggregated macroeconomic and uncertainty variables influence volatility associated with corporate performance among corporate bodies in the USA. Test analysis conducted also features interaction terms, which examine how inflation uncertainty and macroeconomic uncertainty moderate surmise relationships between noted disaggregated explanatory variables and corporate performance volatility. The first interaction terms in Table 6 capture interactions between the various disaggregated explanatory variables and macroeconomic uncertainty. The second interaction terms featured in Table 7 on the other hand examine interaction terms between similar micro-level explanatory variables and inflation uncertainty. These tests are designed to verify if the two macroeconomic conditions (inflation uncertainty and macroeconomic uncertainty) significantly shape or influence the extent to which various micro-level variables employed in this study impact corporate performance volatility. Before these statistical tests, however, multicollinearity diagnostic tests are performed to verify the potential presence of correlation among predictor variables examined in the study. The multicollinearity test procedure adopted in this study, examines the size of respective variance inflation factor (VIF). This study adopts the VIF interpreting rule of thumb proposed by Hair et al. (1995) and Liao and Valliant (2012), respectively; this rule stipulates that tolerance values of greater than 0.10 and VIF values of less than 10 strongly suggest that multicollinearity assumption is not violated in the proposed model. Multicollinearity diagnostic test results presented in Tables 3 and 4 detected presence of multicollinearity in two interaction terms, one on each table; consequently, these interactions terms were dropped from the final error correction estimation examining short-run effects of the various explanatory variables on corporate performance volatility.

\subsection{Unit root tests for stationary conditions}

Stability or stationary conditions of the main variables examined in this study are verified via unit root test procedures. First, optimum lag orders for the estimations are derived through a subsidiary econometric process. The lag order selection in this study is based on the Akaiki

\section{Corporate performance volatility}


$\underset{1,1}{\mathrm{JMB}}$

52

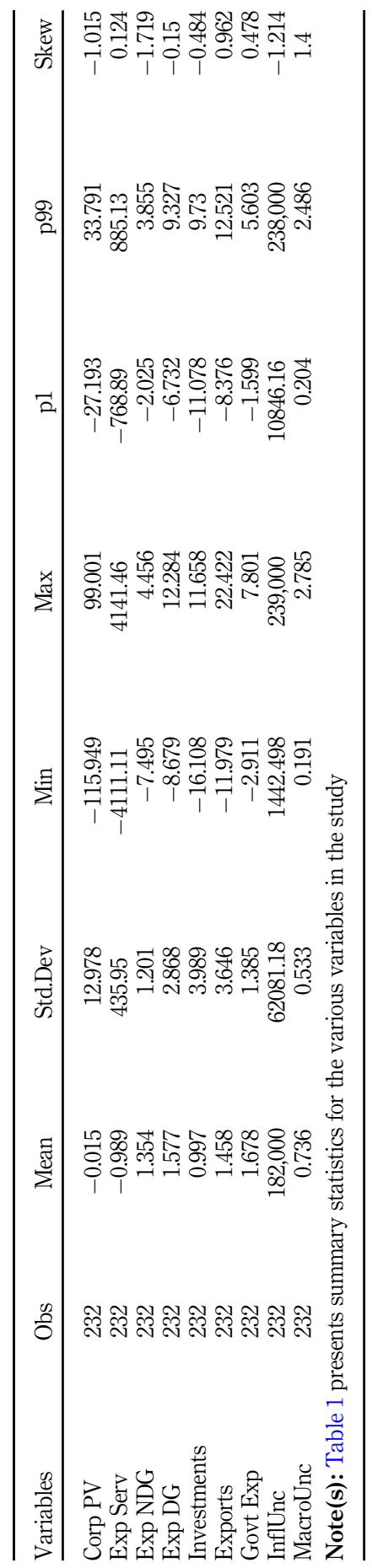

Table 1.

Descriptive statistics

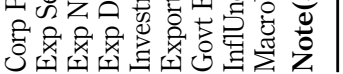




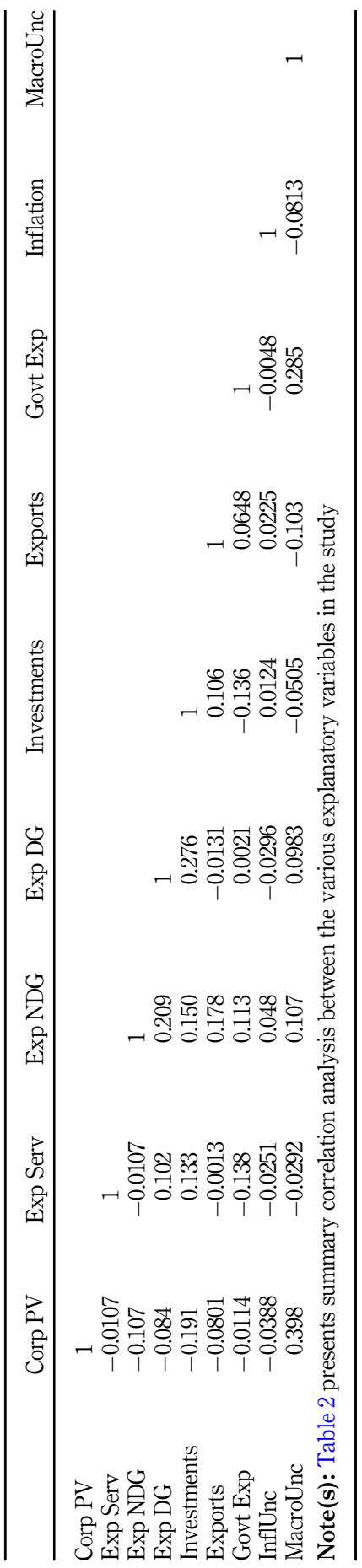

Corporate performance volatility

53

Table 2. Correlation analysis 
$\underset{1,1}{\mathrm{JMB}}$

\begin{tabular}{lcccc}
\hline Variables & VIF & SQRT-VIF & Tolerance & $R$-Sqd \\
\hline Corp PV & 1.48 & 1.22 & 0.6742 & 0.3258 \\
Exp Ser & 1.58 & 1.26 & 0.6341 & 0.3659 \\
Exp NDG & 1.53 & 1.24 & 0.6555 & 0.3445 \\
Exp DG & 1.19 & 1.09 & 0.8421 & 0.1579 \\
Investment & 1.41 & 1.19 & 0.7101 & 0.2899 \\
Exports & 1.14 & 1.07 & 0.8782 & 0.1218 \\
Gov't Exp & 1.01 & 1.01 & 0.989 & 0.011 \\
MacroUnc & 1.69 & 1.3 & 0.5905 & 0.4095 \\
InflUnc & 1.61 & 1.27 & 0.6201 & 0.3799 \\
Exp Ser*MacroUnc & 5.78 & 2.4 & 0.1731 & 0.8269 \\
Exp NDG*MacroUnc & 3.07 & 1.75 & 0.3261 & 0.6739 \\
Exp DG*MacroUnc & 2.57 & 1.6 & 0.3886 & 0.6114 \\
Investment*MacroUnc & 3.36 & 1.83 & 0.2975 & 0.7025 \\
Exports *MacroUnc & 2520.62 & 50.21 & 0.0004 & 0.9996 \\
Gov't Exp*MacroUnc & 2.48 & 1.58 & 0.4029 & 0.5971
\end{tabular}

Table 3.

Gov't Exp*MacroUnc

2.48

1.58

0.5971

Multicollinearity Note(s): Table 3 presents the multicollinearity diagnostic test variance inflation factor associated with various diagnostic test

variables including the interaction terms

Table 4.

Multicollinearity diagnostic test

\begin{tabular}{lcccc}
\hline Variables & VIF & SQRT-VIF & Tolerance & $R$-Sqd \\
\hline Corp PV & 1.48 & 1.22 & 0.6742 & 0.3258 \\
Exp Ser & 1.58 & 1.26 & 0.6341 & 0.3659 \\
Exp NDG & 1.53 & 1.24 & 0.6555 & 0.3445 \\
Exp DG & 1.19 & 1.09 & 0.8421 & 0.1579 \\
Investment & 1.41 & 1.19 & 0.7101 & 0.2899 \\
Exports & 1.14 & 1.07 & 0.8782 & 0.1218 \\
Gov't Exp & 1.01 & 1.01 & 0.989 & 0.011 \\
MacroUnc & 1.69 & 1.3 & 0.5905 & 0.4095 \\
InflUnc & 1.61 & 1.27 & 0.6201 & 0.3799 \\
Exp Ser*InfUnc & 6.65 & 2.58 & 0.1504 & 0.8496 \\
Exp NDG*InflUnc & 2.96 & 1.72 & 0.3383 & 0.6617 \\
Exp DG*InflUnc & 1.52 & 1.23 & 0.6572 & 0.3428 \\
Investment*InflUnc & 3.07 & 1.75 & 0.3262 & 0.6738 \\
Exports *InflUnc & 1234.01 & 35.13 & 0.0008 & 0.9992 \\
Gov't Exp*InflUnc & 1.74 & 1.32 & 0.5757 & 0.4243
\end{tabular}

Note(s): Table 4 presents the multicollinearity diagnostic test variance inflation factor associated with various variables including the interaction terms

Information Criterion (AIC). Augmented Dickey-Fuller (1981) (ADF) and the Phillip and Perron (1988) (PP) unit root tests, respectively, conducted using the AIC suggested optimum lag orders. Table 5 presents results of stationary conditions associated with various study variables. Results in Table 5 suggest that with the exception of inflation uncertainty, all the variables examined in the study are stationary. Ordinarily, first difference of the inflation uncertainty variable would have been used in the final empirical analysis; however, since the empirical framework adopted in this study is not constrained or significantly influence by the order of integration of the variables in treatment as already alluded to, the inflation uncertainty variable is used in subsequent estimation without any differencing procedure. 


\begin{tabular}{|c|c|c|c|c|c|c|}
\hline \multirow[b]{2}{*}{ Variables } & \multicolumn{3}{|c|}{ Augmented Dickey-Fuller test } & \multicolumn{2}{|c|}{ Philip-Perron test } & \multirow{2}{*}{$\begin{array}{r}\text { Corporate } \\
\text { performance } \\
\text { volatility }\end{array}$} \\
\hline & $\begin{array}{l}\text { Optimum } \\
\text { Lag order }\end{array}$ & $\begin{array}{c}\text { Test } \\
\text { Statistic }\end{array}$ & Results & $\begin{array}{c}Z(t) \\
\text { Statistic }\end{array}$ & Results & \\
\hline Corp PV & 4 & $-6.341 * * *$ & $\mathrm{I}(0)$ & $-9.164 * * *$ & $\mathrm{I}(0)$ & \\
\hline Exp Ser & 0 & $-14.47^{* * *}$ & $\mathrm{I}(0)$ & $-14.47^{* * * *}$ & $\mathrm{I}(0)$ & \\
\hline Exp NDG & 1 & $-7.776^{* * * *}$ & $\mathrm{I}(0)$ & $-10.38 * * *$ & $\mathrm{I}(0)$ & \\
\hline Exp DG & 3 & $-6.352^{* * * *}$ & $\mathrm{I}(0)$ & $-16.257 * * *$ & $\mathrm{I}(0)$ & 5 \\
\hline Investment & 1 & $-8.688^{* * *}$ & $\mathrm{I}(0)$ & $-12.764 * * *$ & $\mathrm{I}(0)$ & \\
\hline Exports & 2 & $-8.634 * * *$ & $\mathrm{I}(0)$ & $-19.62^{* * *}$ & $\mathrm{I}(0)$ & \\
\hline Gov't Exp & 4 & $-3.346^{* *}$ & $\mathrm{I}(0)$ & $-14.03 * * *$ & $\mathrm{I}(0)$ & Unit root results using \\
\hline MacroUnc & 1 & $-3.892 * * *$ & $\mathrm{I}(0)$ & $-3.938 * * *$ & $\mathrm{I}(0)$ & $\mathrm{ADF}$ and $\mathrm{PP}$ diagnostic \\
\hline InflUnc & 1 & -1.792 & $\mathrm{I}(1)$ & -1.814 & $\mathrm{I}(1)$ & procedures \\
\hline
\end{tabular}

\subsection{Corporate performance volatility, micro-level variables, inflation uncertainty and macroeconomic uncertainty}

Table 6 presents short-run coefficient estimates of how micro-level explanatory variables influence corporate performance volatility. Results in column 1 in this regard present coefficient estimates of how subcomponents of GDP growth, macroeconomic uncertainty and inflation uncertainty influence corporate performance volatility. Among the explanatory variables examined, results reported in the first column of Table 6 suggest that at the microlevel, only expenditures on services, nondurable goods, durable goods and inflation uncertainty are statistically significant in explaining variability in corporate performance volatility in the short run. Among these variables found to be significant, however, the results further suggest that percentage growth in expenditures on services and nondurable goods tends to reduce or minimize volatility associated with corporate performance, all things being equal. In the same first column, however, the results also suggest that percentage growth in expenditure on durable goods and inflation uncertainty rather worsens corporate performance volatility in the short run. Estimated results in the same column additionally show that in the short run, investment expenditures, net exports and macroeconomic uncertainty have no statistically significant effect on corporate performance volatility over the period examined in the study. These results to some degree suggest that, in the short run, corporate performance volatility among US corporate bodies is shaped largely by ebbs and flows associated with expenditures on services, nondurable goods and durable goods, as well as inflation uncertainty. From the results in column 1 of Table 6 , it is evident that there exist significant divergent relationships between how subcomponents of the same macro-level macroeconomic indicator (GDP growth) influence volatility associated with corporate performance in the short run. For instance, although expenditure on nondurable and durable goods are all micro-components of consumption expenditures, a key component of GDP growth, they tend to exert significantly different influence on corporate performance volatility. Additionally, coefficient estimates presented in column 1 of Table 6 further reinforce the notion that empirical inquires focusing on the effects of macro-level variables such as GDP growth alone may not fully capture or explain the underlying spectrum of effects subcomponents of the same variable may have on a dependent variable of interest, all things being equal.

Error correction coefficient $\left(\mathrm{ECM}_{t-1}\right)$ results in Table 6 are all significant and negative, suggesting convergence toward long-run equilibrium following any impulse shock in the short run. The negative $\mathrm{ECM}_{t-1}$ coefficient reported in column 1 of Table 6 suggests that deviations from long-run equilibrium due to shocks are corrected at a slower pace given the relatively small negative coefficient estimate. From the above analysis, it is evident that the 
$\underset{1,1}{\mathrm{JMB}}$

56

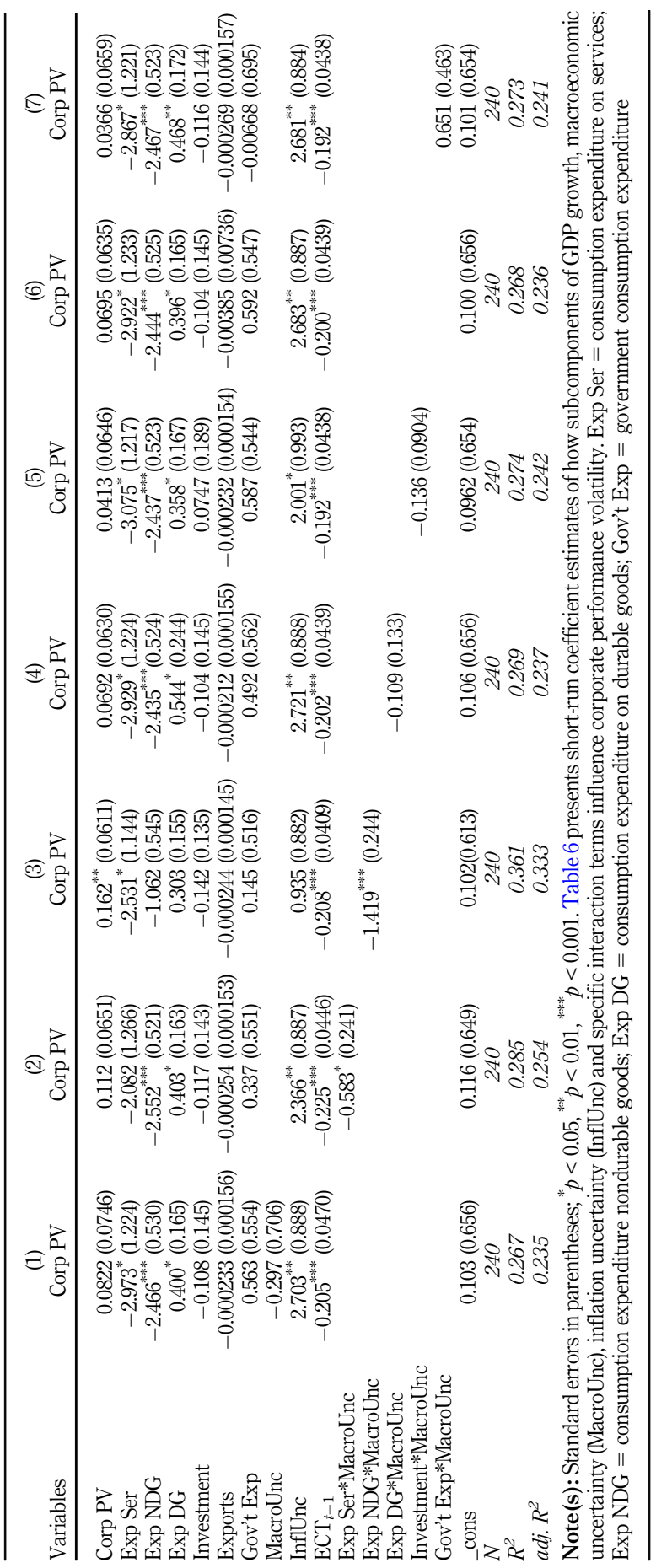

Table 6.

Micro-level

determinants of

corporate performance

volatility - moderating role of macroeconomic uncertainty 
micro-level approach or subcomponents analysis adopted in this study significantly improves chances of detecting and understanding the mechanics of micro-level relationships often lost in studies that focus primarily on the effects of aggregate variables such as GDP growth. For instance, divergent results on how subcomponents of the same aggregate variable (GDP growth) influence corporate performance volatility captured in column 1 of Table 6 may not have been apparent if the focus had been on direct impact of GDP growth on corporate performance volatility. These findings to a large extent support the presumption made earlier that empirical analysis based on aggregate indicators such as GDP growth may fail to reveal critical subcomponent relationships that may be crucial for strategic decisionmaking in the ever-evolving business environment. For instance, for strategic planning, it may be crucial for managers to appreciate how subcomponent variables influence efforts at managing performance volatility. In this regard, growth in expenditures on services and nondurable goods constitutes a welcoming news for such managers and investors because such a condition augments efforts in minimizing volatility associated with performance, all things being equal. On the other hand, however, growth in expenditures on durable goods may be a cue to managers to trigger measures designed to minimized performance volatility because of the verified impact of the variable on performance volatility. It is crucial to point out that this study subscribes to the view that volatility or extreme swings in performance may hurt investor confidence in a business environment where stability and certainty is key to realizing forecasted objectives. Persistent or extreme fluctuations in performance in this regard may engender uncertainty, deter potential investors and stifle needed investments growth.

\subsection{Corporate performance volatility and the moderating role of macroeconomic uncertainty}

Columns 2 to 7 of Table 6 present similar analysis as examined in column 1; however, these columns include interaction terms between each subcomponent variable and macroeconomic uncertainty. Interaction terms in this instance are designed to examine the extent to which macroeconomic uncertainty influences or moderates relationships between the various micro-level variables and corporate performance volatility. Reported results suggest that among the variables examined, macroeconomic uncertainty is significant in moderating relationships between expenditures on services, nondurable goods and corporate performance volatility. The results of the interaction between macroeconomic uncertainty and expenditures on services suggest that macroeconomic uncertainty somehow weakens the extent to which growth in expenditure on services influence volatility associated with corporate performance. In order words, in a macroeconomic environment characterized by uncertainty, effects of services consumption expenditure on volatility associated with corporate performance, as verified in the first part of column 1 of Table 6 , are significantly constrained, all things being equal. Additionally, the coefficient estimate of the interaction between expenditure on nondurable goods and macroeconomic uncertainty also suggest that the effect of expenditure on nondurable goods on corporate performance volatility is significantly suppressed in a business environment characterized by macroeconomic uncertainty. This conclusion is also evident from the negative coefficient associated with the interaction term. In order words, comparatively, growth in expenditures on services and nondurable goods tends to have a much less impact in reducing corporate performance volatility in a macroeconomic environment characterized by macroeconomic uncertainty.

The above analysis suggests that in the short run, micro-level variables of the same aggregate variable tend to exert a significant divergent impact on corporate performance volatility, and that such impacts are significantly influenced by macroeconomic conditions such as macroeconomic uncertainty.

\section{Corporate performance volatility}


$\underset{1,1}{\mathrm{JMB}}$

Table 7 presents short-run coefficient estimates on the relationship between corporate performance volatility and already-defined micro-level explanatory variables. However, instead of the moderating role of the macroeconomic uncertainty variable, results presented in Table 7 rather examine the interaction effect of inflation uncertainty, another macroeconomic condition on the various explanatory variables, and how such interactions ultimately influence corporate performance volatility. The results presented in Table 7 suggest that among the various explanatory variables examined, percentage growth in expenditures on services and nondurable goods tends to reduce volatility associated with corporate performance, whereas growth in consumption expenditure on durable goods and inflation uncertainty rather worsens volatility in corporate performance.

\subsection{Corporate performance volatility and the moderating role of inflation uncertainty}

Columns 2 to 7 of Table 7 present empirical estimates of the effects of the interaction between inflation uncertainty and noted micro-level explanatory variables, and how such interactions influence corporate performance volatility. Interaction between net exports and inflation uncertainty is omitted from this analysis because of multicollinearity based on VIF analysis discussed earlier. Interaction term results presented in Table 7 suggest that inflation uncertainty significantly moderates the extent to which expenditures on services, nondurable goods, durable goods and investments influence corporate performance volatility in the short run. For micro-level variables such as expenditure on services and nondurable goods, the moderating impact from inflation uncertainty diminishes the extent to which these individual variables influence corporate performance volatility. From the interaction term between expenditure on durable goods and inflation uncertainty, it is also evident that inflation uncertainty does not only moderate the extent of influence but could also alter the direction of influence $(-$ or +$)$ the explanatory variable has on the dependent variable, all things being equal. Results presented in Table 7 further suggest that growth in government expenditures in a heightened inflationary uncertain environment rather worsens or increases corporate performance volatility (Gov't Exp*InflUnc $\left.=0.973^{*}\right)$. From the results reported in Table 7, it is evident that inflationary uncertainty tends to have a significant moderating impact on how some of the explanatory variables influence variability in corporate performance. Thus, inflation uncertainty as a macroeconomic condition per these results has the potential to either constrain or significantly alter how micro-level variables influence corporate performance volatility. Consistent with the results presented in Table 6, error correction coefficients $\left(\mathrm{ECM}_{t-1}\right)$ captured in the various columns are all significant and negative, suggesting that deviations from long-run equilibrium due to shocks are corrected at a much slower pace per $\mathrm{ECM}_{t-1}$ coefficients.

The above results and analysis point to significant divergent among micro-level variables of the same aggregate variable in how they influence a dependent variable of interest, in this instance, corporate performance volatility. Reported results further suggest that macroeconomic conditions such as inflation uncertainty and macroeconomic uncertainty significantly moderate the extent to which noted micro-level variables ultimately influence performance dynamics among corporate entities. Additionally, submitted analysis makes the case for why aggregate variables such as GDP growth may fail to capture the full array of unique underlying relationships exhibited by its subcomponents. Empirical results presented in this regard, suggest that all things being equal, "the whole might not necessarily reflect unique features exhibited by its subcomponents". In order words, the effect of the aggregate variable such as GDP growth on any performance indicator might be significantly different from what its individual subcomponents may exhibit. This study has thus offered a perspective on how subcomponent variables influence corporate performance in a form that is distinct from what the existing literature provides. 


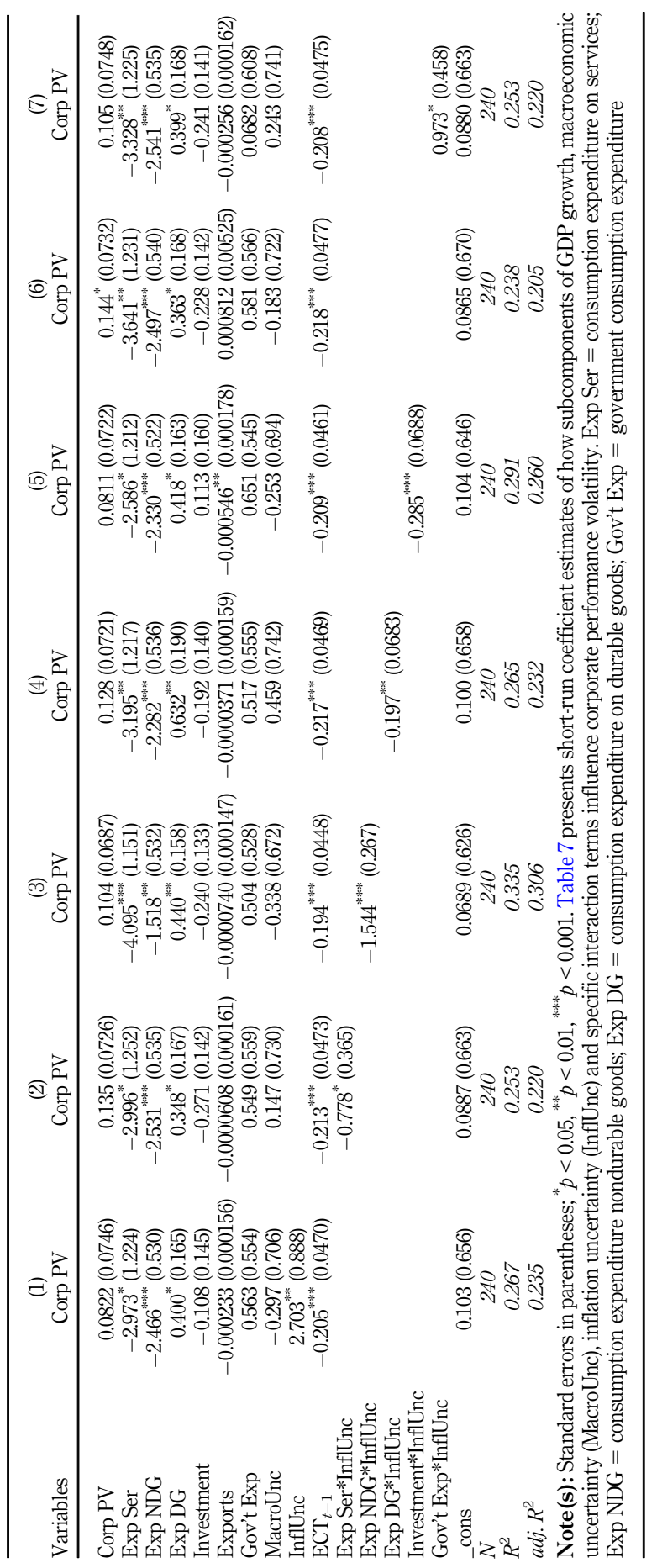
Corporate performance volatility

59

Table 7

Micro-level determinants of corporate performance volatility - moderating role of inflation uncertainty 
$\underset{1,1}{\mathrm{JMB}}$

\section{Conclusions}

Compared to most reviewed studies on firm/corporate performance, this study presented a different approach to examining the dynamics of corporate performance volatility. The study focuses on how subcomponents of a key macroeconomic variable, inflation uncertainty and macroeconomic uncertainty, influence corporate performance volatility in the short run. The approach adopted in this study augments the related literature in two major ways: first, this study focuses on volatility associated with corporate performance instead of the corporate performance variable itself as done in most related studies. Additionally, empirical analysis performed in the study focused on the role of disaggregated or micro-level variables or subcomponents of a key macroeconomic variable, and how such variables influence corporate performance volatility. The study employed the ARDL model in its empirical analysis. Estimated results suggest that, all things being equal, growth in expenditures on services and nondurable goods tend to suppress volatility associated with corporate performance. Reported empirical results further suggest that growth in expenditure on durable goods and inflation uncertainty rather exacerbate volatility associated with corporate performance, all things being equal. Additionally, this study finds that macroeconomic conditions such as inflation uncertainty and macroeconomic uncertainty significantly moderate how subcomponent variables examined in the study influence corporate performance volatility. For instance, interaction terms between expenditures on services and nondurable goods and inflation uncertainty/macroeconomic uncertainty, respectively, suggest a significant moderating impact of the two macroeconomic conditions on how the two variables influence corporate performance volatility.

The micro-level approach adopted in the study has provided insight on micro-level interactions hitherto unobserved in similar empirical inquiries. Apart from the academic significance of the various findings presented above, the main findings of this empirical inquiry could also have significant policy implication for key corporate policy makers. For instance, policy makers could take a cue from how the various disaggregated variables impact performance volatility in the development of tailored strategic policies geared toward minimizing such performance volatility. Additionally, fundamental associations identified between various disaggregated macroeconomic variables and corporate performance volatility could aid policy makers in pre-empting and planning for potential volatility in performance by putting in place appropriate mitigating measures.

\section{Notes}

1. (e.g. $\mathrm{ROA}=$ return on assets, $\mathrm{ROE}=$ return on equity, $\mathrm{NIM}=$ net interest margin, etc).

2. The study provides succinct review of the literature on corporate performance. However, corporate performance is not the focus in the study per se; this study rather focuses on corporate performance volatility and the role of sub-components of key macroeconomic variables.

3. The inflation variable serves as the base variable from which the inflation uncertainty variable is derived using the GARCH $(1,1)$ process noted above.

4. The ARDL procedure employed in the study is not constrained by the nature of integration of test variables; that is, whether variables are integrated in order I(0), I(1) or mutually cointegrated.

\section{References}

Adams, R.B., Almeida, H. and Ferreira, D. (2005), "Powerful CEOs and their impact on corporate performance", The Review of Financial Studies, Vol. 18 No. 4, pp. 1403-1432.

Agustinus, P. and Rachmadi, P. (2008), "Determinants of corporate performance of listed companies in Indonesia”, MPRA Paper No. 6777. 
Ahmed, I. and Qayyum, A. (2007), "Do public expenditure and macroeconomic uncertainty matter to private investment? Evidence from Pakistan”, The Pakistan Development Review, Vol. 42 No. 2, pp. 145-161.

Al-Homaidi, E.A., Almaqtari, F.A., Yahya, A.T. and Khaled, A.S. (2020), "Internal and external determinants of listed commercial banks' profitability in India: dynamic GMM approach", International Journal of Monetary Economics and Finance, Vol. 13 No. 1, pp. 34-67.

Alam, I. and Quazi, R. (2003), "Determinants of capital flight: an econometric case study of Bangladesh", International Review of Applied Economics, Vol. 17 No. 1, pp. 85-103.

Apadore, K. and Zainol, S.S.B. (2014), "Determinants of corporate governance and corporate performance among consumer product industry in Malaysia: a theoretical model", International Journal of Academic Research in Accounting, Finance and Management Sciences, Vol. 4 No. 2, pp. 159-165.

Aras, G., Aybars, A. and Kutlu, O. (2010), "Managing corporate performance", International Journal of Productivity and Performance Management, Vol. 59 No. 3, pp. 229-254.

Asimakopoulos, I., Samitas, A. and Papadogonas, T. (2009), "Firm-specific and economy wide determinants of firm profitability: Greek evidence using panel data”, Managerial Finance, Vol. 35 No. 11, pp. 930-939.

Asteriou, D. and Price, S. (2005), "Uncertainty, investment and economic growth: evidence from a dynamic panel", Review of Development Economics, Vol. 9 No. 2, pp. 277-288.

Baños-Caballero, S., García-Teruel, P.J. and Martínez-Solano, P. (2014), "Working capital management, corporate performance, and financial constraints", Journal of Business Research, Vol. 67 No. 3, pp. 332-338.

Banerjee, A. and De, A. (2014), "Determinants of corporate financial performance relating to capital structure decisions in Indian iron and steel industry: an empirical study", Paradigm, Vol. 18 No. 1, pp. 35-50.

Barakat, M.R., Elgazzar, S.H. and Hanafy, K.M. (2016), "Impact of macroeconomic variables on stock markets: evidence from emerging markets", International Journal of Economics and Finance, Vol. 8 No. 1, pp. 195-207.

Becchetti, L., Di Giacomo, S. and Pinnacchio, D. (2008), "Corporate social responsibility and corporate performance: evidence from a panel of US listed companies”, Applied Economics, Vol. 40 No. 5, pp. 541-567.

Bollerslev, T. (1986), "Generalized autoregressive conditional heteroskedasticity", Journal of Econometrics, Vol. 31 No. 3, pp. 307-327.

Bruno, V. and Shin, H.S. (2014), "Globalization of corporate risk taking", Journal of International Business Studies, Vol. 45 No. 7, pp. 800-820.

Byrne, B.M. (2010), Structural Equation Modeling with AMOS: Basic Concepts, Applications, and Programming, Routledge, New York, NY.

Chapsa, X., Katrakilidis, C. and Tabakis, N. (2011), "Dynamic linkages between output growth and macroeconomic volatility: evidence using Greek data", International Journal of Economic Research, Vol. 2 No. 1, pp. 152-165.

Coad, A. (2009), The Growth of Firms: A Survey of Theories and Empirical Evidence, Edward Elgar Publishing, Cheltenham.

Demsetz, H. and Villalonga, B. (2001), "Ownership structure and corporate performance”, Journal of Corporate Finance, Vol. 7 No. 3, pp. 209-233.

Dickey, D. and Fuller, W.A. (1981), "Likelihood Ratio statistics for autoregressive time series with a unit root", Econometrica, Vol. 49 No. 4, pp. 1057-72.

Doan, T. (2020), "Profitability of real estate firms: evidence using GMM estimation", Management Science Letters, Vol. 10 No. 2, pp. 327-332.

Doruk, Ö.T. (2019), "Macroeconomic determinants of firm performance: evidence from Turkey", The Singapore Economic Review, pp. 1-20. 
JMB 1,1

Engle, R.F. (1982), “Autoregressive conditional heteroscedasticity with estimates of the variance of United Kingdom inflation”, Econometrica, Vol. 50 No. 4, pp. 987-1007.

Faccio, M., Marchica, M.T. and Mura, R. (2011), "Large shareholder diversification and corporate risktaking”, The Review of Financial Studies, Vol. 24 No. 11, pp. 3601-3641.

Fang, W., Miller, S.M. and Lee, C. (2008), "Cross-country evidence on output growth volatility: nonstationary variance and GARCH models", Scottish Journal of Political Economy, Vol. 55 No. 4, pp. 509-541.

Fountas, S. and Karanasos, M. (2007), "Inflation, output growth, and nominal and real uncertainty: empirical evidence for the G7”, Journal of International Money and Finance, Vol. 26 No. 2, pp. 229-250.

Geetha, C., Mohidin, R., Chandran, V.V. and Chong, V. (2011), "The relationship between inflation and stock market: evidence from Malaysia, United States and China”, International Journal of Economics and Management Sciences, Vol. 1 No. 2, pp. 1-16.

George, D. and Mallery, M. (2010), SPSS for Windows Step by Step: A Simple Guide and Reference, 17.0 Update, 10a ed., Pearson, Boston.

Grazzi, M., Jacoby, N. and Treibich, T. (2016), "Dynamics of investment and firm performance: comparative evidence from manufacturing industries”, Empirical Economics, Vol. 51 No. 1, pp. 125-179.

Hair, J.F. Jr, Anderson, R.E., Tatham, R.L. and WilliamBlack, C. (1995), Multivariate Data Analysis with Readings, Prentice Hall, New Jersey, NJ.

Hair, J., Black, W.C., Babin, B.J. and Anderson, R.E. (2010), Multivariate Data Analysis, 7th ed., Pearson Educational International, Upper Saddle River, New Jersey, NJ.

Hansen, G.S. and Wernerfelt, B. (1989), "Determinants of firm performance: the relative importance of economic and organizational factors”, Strategic Management Journal, Vol. 10 No. 5, pp. 399-411.

Igbinosa, S. (2015), "Another look at capital structure and corporate performance in emerging markets: the case of Nigeria”, Asian Journal of Business Management, Vol. 7 No. 1, pp. 1-12.

Islam, M.S. and Sahajalal, M. (2021), "Strategically determinants the impact of macroeconomic factors on pharmaceutical companies profitability in Bangladesh", Asian Journal of Advances in Research, Vol. 7 No. 3, pp. 32-36.

Issah, M. and Antwi, S. (2017), "Role of macroeconomic variables on firms' performance: evidence from the UK", Cogent Economics and Finance, Vol. 5 No. 1, p. 1405581.

Kemper, J., Schilke, O., Reimann, M., Wang, X. and Brettel, M. (2013), "Competition-motivated corporate social responsibility”, Journal of Business Research, Vol. 66 No. 10, pp. 1954-1963.

Killins, R.N. (2020), "Firm-specific, industry-specific and macroeconomic factors of life insurers' profitability: evidence from Canada”, The North American Journal of Economics and Finance, Vol. 51, p. 101068.

Lee, J. (2010), "The link between output growth and volatility: evidence from a GARCH model with panel data”, Economics Letters, Vol. 106, pp. 143-145.

Liao, D. and Valliant, R. (2012), "Variance inflation factors in the analysis of complex survey data", Survey Methodology, Vol. 38 No. 1, pp. 53-62.

Mahadalle, A. and Kaplan, B. (2017), "Entrepreneurial characteristics and competencies as determinants of corporate performance: a study on small enterprises in Mogadishu, Somalia”, International Journal of Research-Granthaalayah, Vol. 5 No. 5, pp. 243-254.

Ntim, C.G. and Osei, K.A. (2011), "The impact of corporate board meetings on corporate performance in South Africa”, African Review of Economics and Finance, Vol. 2 No. 2, pp. 83-103.

Nunes, P.M., Mendes, S. and Serrasqueiro, Z. (2012), "SMEs' investment determinants: empirical evidence using quantile approach”, Joumal of Business Economics and Management, Vol. 13 No. 5, pp. 866-894.

Palaniappan, G. (2017), "Determinants of corporate financial performance relating to board characteristics of corporate governance in Indian manufacturing industry”, European Journal of Management and Business Economics, Vol. 26 No. 1, pp. 67-85. 
Panda, A.K., Nanda, S. and Panda, P. (2021), "Working capital management, macroeconomic impacts, and firm profitability: evidence from Indian SMEs", Business Perspectives and Research, Vol. 9 No. 1, pp. 144-158.

Pantea, M., Gligor, D. and Anis, C. (2014), "Economic determinants of Romanian firms' financial performance", Procedia-Social and Behavioral Sciences, Vol. 124, pp. 272-281.

Perić, M. and Đurkin, J. (2015), "Determinants of investment decisions in a crisis: perspective of Croatian small firms", Management: Journal of Contemporary Management Issues, Vol. 20 No. 2, pp. 115-133.

Pervan, M. and Višić, J. (2012), "Influence of firm size on its business success", Croatian Operational Research Review (CORR), Vol. 3, pp. 213-223.

Pesaran, M.H., Shin, Y. and Smith, R.J. (2001), "Bounds testing approaches to the analysis of level relationships", Journal of Applied Econometrics, Vol. 16, pp. 289-326.

Phillips, P.C.B. and Perron, P. (1988), "Testing for unit roots in time series regression”, Biometrika, Vol. 75 , pp. 335-346.

Putra, I., Novitasari, L.G., Mahaputra, I. and Sudiartana, I. (2021), "The influence of macroeconomic indicators on profitability: a case study of regional development banks in Indonesia", The Journal of Asian Finance, Economics and Business, Vol. 8 No. 6, pp. 79-87.

Rahman, H.U., Yousaf, M.W. and Tabassum, N. (2020), "Bank-specific and macroeconomic determinants of profitability: a revisit of Pakistani banking sector under dynamic panel data approach", International Journal of Financial Studies, Vol. 8 No. 3, p. 42.

Rezina, S., Ashraf, A. and Khan, M.A. (2020), "An inferential study on the profitability determinants of the cement industry in Bangladesh", Asian Finance and Banking Review, Vol. 4 No. 2, pp. 8-21.

Shu, Y., Broadstock, D.C. and Xu, B. (2013), "The heterogeneous impact of macroeconomic information on firms' earnings forecasts", The British Accounting Review, Vol. 45 No. 4, pp. 311-325.

Sir, M.M. (2012), "Impact of the macroeconomic variables on the stock market returns: the case of Germany and the United Kingdom", Global Journal of Management and Business Research, Vol. 12 No. 16, pp. 22-34.

Triandafil, C.M., Brezeanu, P. and Badea, L. (2010), "Macroeconomic impact on CEE corporate profitability: analysis at the level of companies listed on the bucharest stock exchange", Theoretical and Applied Economics, Vol. XVII No. 10 (551), pp. 5-14.

Utama, C.A. and Sulistika, M. (2015), "Determinants of investment opportunity set (degree of internationalization and macroeconomic variables)", Gadjah Mada International Journal of Business, Vol. 17 No. 2, pp. 107-124.

Zeitun, R. and Tian, G.G. (2007), "Capital structure and corporate performance: evidence from Jordan", Australasian Accounting, Business and Finance Journal, Vol. 1 No. 4, pp. 1-24.

Zeitun, R., Tian, G.G. and Keen, S. (2007), "Macroeconomic determinants of corporate performance and failure: evidence from an emerging market the case of Jordan", Corporate Ownership and Control, Vol. 5 No. 1, pp. 179-194.

\section{Further reading}

Prasetyantoko, A. and Rachmadi, P. (2008), "Determinants of corporate performance of listed companies in Indonesia”, MPRA Paper, 2008.

\section{Corresponding author}

Rexford Abaidoo can be contacted at: rabaidoo@umes.edu

For instructions on how to order reprints of this article, please visit our website:

www.emeraldgrouppublishing.com/licensing/reprints.htm

Or contact us for further details: permissions@emeraldinsight.com 